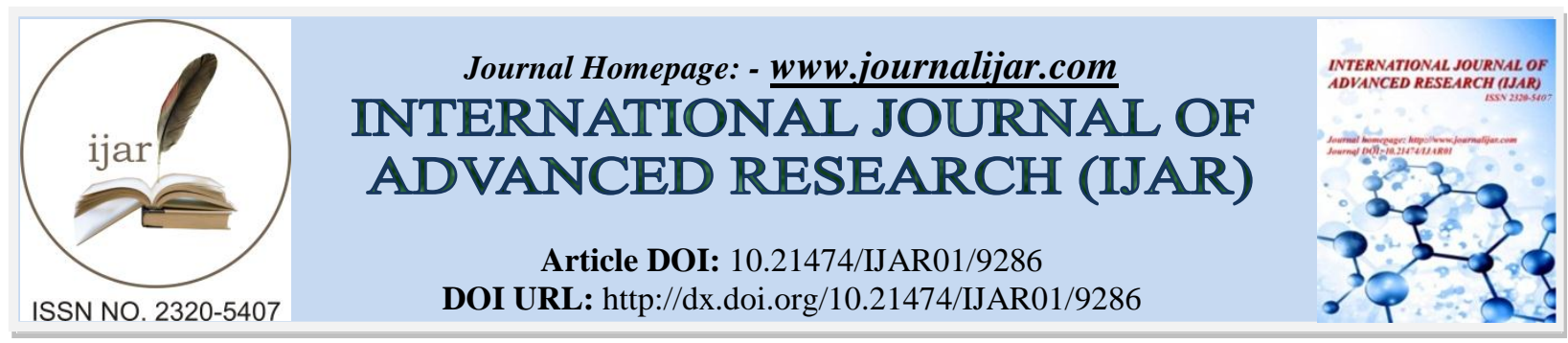

RESEARCH ARTICLE

\title{
A REVIEW ON RECENT ADVANCES IN THE MANAGEMENT OF BHAGANDARA (FISTULA-IN- ANO).
}

Lawate Uday ${ }^{1}$ and Wairagade Sushil ${ }^{2}$.

1. PG Scholar, Shalyatantra Department, Government Ayurved College and Hospital, Nagpur.

2. Assistant professor, Shalyatantra Department, Government Ayurved College and Hospital, Nagpur.

\section{Manuscript Info}

Manuscript History

Received: 15 April 2019

Final Accepted: 17 May 2019

Published: June 2019

Key words:-

Bhagandara, Ashtomahagada, LIFT, IFTAK, FiLaC.

\section{Abstract}

Bhagandara is one of Ashtomahagada described by Acharya Sushruta as it is difficult to cure. Bhagandara is a track lined by unhealthy granulation tissue and can be correlated with Fistula in Ano. It is a disease that has plagued humanity since time immemorial. The anal fistula most common illness affecting the male gender globally. For the management of Bhagandara (Fistula in ano) number of surgical treatment modalities are available but their limitations and complications are developed hence it is still big challenge to surgeons to treat especially of complex and recurrent fistula in ano (Bhagandara) hence it is notorious disease.

In Ayurveda Sushruta has described various types of treatment modalities like Chedana karma, Ksharsutra therapy, and in modern science Fistulectomy, Fistulotomy is the choice of treatment. Fistula is a chronic state of Anorectal infection, the main concern of fistula in ano is duration of treatment and recurrence. Hence in Ayurveda and modern science many technique develops to reduce these complications, like Interception of Fistulous Tract with Application of Ksharsutra (IFTAK), Ligation of Intersphincteric Fistula Tract (LIFT), Seton placement etc. are the recent advance treatment modalities available for management of Bhagandara.

Copy Right, IJAR, 2019,. All rights reserved.

\section{Introduction:-}

The disease in which Darana (deformity) in and around Bhaga (pubic region, perineum, genital area), Guda (anal region) and Basti (urinary bladder) is called as Bhagandara. When the blisters remains unripe (not suppurated) it is called Pidaka, when the same get suppurated it will be called Bhagandara ${ }^{[1]}$. It is a painful disease having symptoms like Kandu, Daha, Shoth(Swelling), pus discharge from anal and perianal region ${ }^{[2]}$. It is correlated with fistula in ano means a communicating abnormal track with an external opening in the perianal skin region and internal opening in the anal mucosa or rectum. According to Sushruta there are five types of Bhagandara which is Shatponaka, Ushtragriva, Paristravi, Shambukavarta and Unmargi. All they are Kricchasadhya (difficult to cure) ${ }^{[3]}$, the fistula in ano is complicated due to its recurrence nature.

Study showed that the prevalence of fistula in ano is 8.6 cases per 100000 populations. In men the prevalence is 12.3 cases per 100000 population and in women it is 5.6 cases per 100000 population ${ }^{[4]}$.

Corresponding Author:- Lawate Uday.

Address:- PG Scholar, Shalyatantra Department, Government Ayurved College and Hospital, Nagpur. 
Goal of treatment of Bhagandara (Fistula in ano) is preserving anal functions, continence, permanently eliminate abscess formation and to promote active healing. Fistula surgery is most common cause of faecal incontinence. To avoid these complications new methods of surgery adopted all over the world.

Aim-

To evaluate the literature regarding recent advances in the management of Fistula in Ano.

Objectives-

1) To Review available literature regarding Bhagandara (Fistula in Ano) and its management.

2) To study the detail literature regarding Bhagandara (Fistula in Ano) in Classical text and in modern science.

\section{Methodology-}

Various classical and modern literatures are searched to review the different surgical and Para surgical procedures used for treatment of Bhagandara (Fistula in ano).

Ancient methods of Surgery in Bhagandara (Fistula in Ano)-

Sushruta mentioned Chhedana karma as a treatment for Bhagandara (Fistula in ano) ${ }^{[5]}$.

\section{Shatponaka Bhagandara-}

All communicating small sinuses should be incised first and the main track is left to healed up. After healing of all communicating sinuses, principle sinus in the locality should be excised. The connected abscesses should be respectively incised on the external side, while the unconnected ones should not be opened at the same time in order that they may not run into one another and be thus converted into a wide-mouthed ulcer. the Langalaka, ArdhaLangalaka, Sarvatobhadraka and the Gotirthaka, forms of incision ${ }^{[6]}$ should be the different shapes incision, in a case of a multiple opening Shataponaka.

An incision equal in its two sided is called Langalaka (curvilineal). While the one with one arm longer than the other is named the Ardha-Langalaka. An incision made in the region of the anus in the shape of cross (crucial) and a little removed from the raphe of the perineum, is called the Sarvatobhadraka by men conversant with the shapes of surgical incisions. An incision made by inserting the knife in one side of Bhagandara is called the Gotirthaka (longitudinal).

The Shataponaka type occurring in a person is extremely difficult to cure, the urine and the faecal matter are found in flow out the cavity of such a wide-mouthed ulcers.

\section{Parisravi (exuding) Bhagandara-}

There is bleeding and secretion from the external openings, the sinus and the cavities of pus should be first removed and then cauterized with an alkali. When sinuses become painless and free from discharge should be searched with a probe and the principle sinus should be cut open and again completely cauterized with an alkali.

The incision should be made in the shape of a Kharjura-patra(leaf of the date-palm), Ardha-chandra (half-moon), Chandra-chakra(moons disc), Suchimukha(needles mouth), or Avammukha (with downward mouth) after that the ulcer should be purified with mild cleansing or disinfecting remedies like Anu taila, Yavakshara, Madana etc. ${ }^{[7]}$

\section{Kshara Sutra Therapy-}

The eminent Indian surgeon Sushruta has narrated in his teachings the use of Kshara for cure of fistula in ano. Ksharsutra therapy is a simple and safe minimum invasive para-surgical technique for treatment in all types of fistula in ano including complex and recurrent fistula. ${ }^{[8]}$ Ksharsutra is a unique medicated Barbour thread helps in both cutting as well as drainage of fistulous tract. The cutting and healing of fistulous tract takes place simultaneously hence the possibility of damage to anorectal sphincter muscle is less and chances of incontinence are practically nil. It is a cost effective, day care procedure and hospitalization is not required in majority of the patients. During the course of treatment patient remain ambulatory and can perform routine daily activities normally.

It involves application of a specially prepared medicated thread processed with certain medicinal plant like Snuhi, Arka, Apamarga etc. The thread is passed in to tract, tied outside the anal aperture and left in situ for seven days after which it is changed and retied. The patient is sent home after each sitting and is advised to continue his routine 
work. In due course of time, the thread falls out spontaneously and the fistulous tract is simultaneously healed. The resultant scar formation is very minimal and the method is safe and free from any complication.

\section{Recent method of Surgery in Ayurveda-}

IFTAK (interception of fistulous tract with application of Ksharsutra):

This novel technique IFTAK (Interception of fistulous tract with application of Ksharsutra) for the treatment of fistula in ano is a modified technique of Ksharsutra therapy. ${ }^{[9]}$ This technique is being practiced for treating all type of fistula including complex and recurrent fistula. In this technique interception of proximal part of fistulous tract is done at intersphincteric plane along with application of Ksharsutra from site of interception to the infected crypt in anal canal. This technique is aimed to eradicate the infected anal crypt without damage to anal sphincters by using Ksharsutra. continuous drainage of any associated abscess cavity in intersphincteric plane, preventing recurrence, make surgical approach to managing the fistula in ano easy by converting the complex nature of fistula into a simple one, reduce the duration of time to complete cure of fistula, allowing an early return to normal activity for the patient. It is being observed that complete cure of complex fistula in ano with a highest success rate and almost negligible recurrence rate.

This technique of treatment is based on the Park's concept of crypto glandular origin of fistula in ano ${ }^{[10]}$. The basis of the procedure is to eradicate the infected anal crypts at the pectinate line using a Ksharsutra (medicated Seton) without laying open of the tract distal to the site of interception. The important steps involve in this technique include, identification of the infected anal crypt, interception of fistulous tract at intersphincteric plane and application of ksharsutra from the site of interception into the infected anal crypt. The fistulous tract is intercepted at the intersphinteric plane and separated from its distal portion.

\section{Methods of Surgery according to modern science- Fistulotomy-}

It is applied mainly in intersphincteric fistula and tran-sphincteric fistula involving less than $30 \%$ of the voluntary musculature. Laying open technique are widely practiced for simple intersphincteric and low transsphincteric fistulas, the patient is placed in the Lithotomy position. Once the course of fistula has been accurately located a blunt probe is inserted from the external opening along the tract to the internal opening at the dentate line. The tissue overlying the probe is incised using a scalpel blade or cutting diathermy and the granulation tissue curetted and sent for pathologic evaluation.

The goal of the fistulotomy is to prevent the recurrence of perianal sepsis while minimizing disruption of sphincter morphology and function. ${ }^{[11]}$

\section{Fistulectomy-}

Either probe is passed through external opening or the external opening is grasped with tissue forcep or stay suture. After dividing the skin around the external opening the tissue around the fistula is filtrated with local anaesthetic agent to reduce bleeding.

After dividing the skin, fine scissor is used to core out the surrounding tissues, leaving the granulating track and its surrounding fibrous tissue, which is withdrawn by gentle traction.

Although excision of the fistula or fistulectomy was thought to be a satisfactory method of treatment of fistula-inano, its use is no longer recommended. Larger wounds are created significantly prolongs wound healing peroid. A greater separation of muscle ends occurs and there is greater risk of injuring or excising underlying muscle thereby increasing the risk of incontinence. ${ }^{[12]}$

\section{Seton-}

The seton is used to drain pus, allow staged division and deliberately cut through sphincter. The problem of preserving anal continence and treating the fistula is more complicated when managing high trans-sphincteric fistulas. If the tract is seen to cross the sphincter muscle at a high level, the use of the lay open technique in combination with insertion of a seton is safer. A seton may be any foreign substance that can be inserted into the fistulous tract to encircle the sphincter muscles. Materials frequently used include silk or other nonabsorbable suture material, Prolene, rubber bands, stainless steel and silastic catheters. The lower portion of the internal anal sphincter is divided along with the skin to reach the external opening and a nonabsorbable suture or elastic suture is inserted 
into the fistulous tract. The ends of the suture or elastic are tied with multiple knots to create a handle for manipulation. This form of seton, known as a cutting seton, is tightened at regular intervals to slowly cut through the sphincter. This allows the tract to become more superficial, converting a high fistula into a low one. The proximal fistulotomy subsequently heals by stimulating fibrosis behind it re-establishing continuity of the anorectal ring to prevent separation of the sphincter muscle at a second-stage repair 8 weeks later when the remaining external sphincter is divided. ${ }^{[13]}$ To preserve the external sphincter in trans-sphincteric fistulae. Secondary tracks in the ischiorectal fossa are laid open.

\section{Recent methods of Surgery According to modern science- Ligation of the Intersphincteric Fistula Tract (LIFT)-}

In this procedure the patient is placed in lithotomy postion and done in usually under monitored anesthesia care and a local anesthetic block. The anal canal is examined with a speculum. The outer opening is cannulated with an injecting catheter and hydrogen peroxide is instilled. One identifies the internal opening within the anal canal. A probe is placed from outside in and left in place. A curvilinear small incision is made over the intersphincteric groove (between internal and external sphincters) and the plane is advanced to incorporate the fistula tract without dividing any of the sphincter muscles. Then tract is gently debrided or scraped from the internal opening to the external opening to get rid of inflammatory tissue. The tract is then divided in the intersphincteric groove very close to the internal opening and from outside along the external portion of the tract. The fistula is then divided between ties. The internal opening is then sutured closed and external opening is left open to dry. The inter-sphincteric incision is then closed in layers. ${ }^{[14]}$ It is a sphincter preserving procedure, there by maintaining continence.

\section{Video-assisted Anal Fistula Treatment (VAAFT)-}

VAAFT is performed with help of fistuloscope, the patient is placed in the lithotomy position and correctly locate the internal fistula opening and possible secondary tracts or abscess cavities. The anal canal is held open using a speculum and irrigation solution is used to give a clear view of the fistulas tract. Light from the fistuloscope can be seen from inside the anal canal at internal opening of the fistula through slit proctoscope and unipolar electrode under video guidance is used to cauterise content of the fistulas tract. Necrotic material is removed at the same time using the fistula brush and forceps, as well as by continuous irrigation, internal opening is closed from inside the anal canal using stiches and staples. The VAAFT procedure is done in two phases diagnostic and operative. It is designed to only affect the fistula tract, preserving sphincter muscle function and faecal continence. ${ }^{[15]}$

\section{Fistula Laser Closure (FiLaC)-}

With other techniques the principal reasons for recurrence and incontinence of Fistula in ano is insufficient drainage of the intersphincteric space, missed and untreated internal openings, missed side tracks or retained remnants of fistula epithelium and granulation tissue. The FiLaC approach is designed to destroy both the crypts gland and the additional epithelial layer of fistula track simultaneously by a photothermal effect with coincident obliteration of both the internal and external fistula orifices. It is a novel sphincter saving procedure for the treatment of anal fistula. closure of the fistula track is achieved using laser energy emitted by a radial fibre connected to a diode laser. The energy causes shrinkage of the unhealthy tissue around the radial fibre with the aim being to close the fistula track. the patient underwent spinal anaesthesia and is positioned in lithotomy. Antibiotic prophylaxis and bowel preparation one day before surgery. After recognition of the external orifice, fistulae catheterization is performed with probe, cleaning with saline irrigation and miomucosal flap with resection of the internal orifice. Insertion of the laser fiber through the external to internal orifice, activation of laser and gradual withdrawal $5 \mathrm{~mm}$ fiber every $3 \mathrm{~s}$, from the internal to the external orifice with simultaneous destruction and sealing of paths. The fiber laser diode used is a radial emission wavelength $1470 \mathrm{~nm}$ and generator was set to $13 \mathrm{~W}$ continuously. At the end of procedure, the miomucosal flap was sutured, covering the area of the internal orifice and made resection of the external orifice for proper drainage of the wound. Among the adverse effects are pain, tenesmus and soiling is most common. A major disadvantage of this method is the cost of laser fiber ${ }^{[16]}$.

\section{Result and Conclusion-}

The advance surgical techniques used in Bhagandara to over comes the demerits of previous surgical procedures. After referring various ancient textbook and modern books, the various treatment modalities of Para surgical and surgical procedures are effective with minimal complications and recurrence with early recovery of patient. Each procedure has its own merits and demerits applicable in different types of fistulae. 


\section{Discussion:-}

According to review of literature regarding Bhagandara (Fistula in ano) disease is described as notorious disease. because after surgery like Ancient methods (Langalaka, Ardhalangalaka etc.), Fistulectomy, fistulotomy the main complications developed are large wound size, long period for wound healing, Recurrence and Incontinence.

Hence now days to overcome the above draw backs new treatment modalities(surgical) procedures are available, In Ayurvedic Ksharsutra therapy the level of action and time duration of these techniques to heal fistulous track varies from four weeks to eight weeks and act by cutting and healing the track simultaneously. IFTAK is modified technique of Ksharsutra therapy for long tract fistula in ano as it is safe, cost effective, less time taken in wound healing, minimum scaring of tissues, minimum chances of faecal incontinence and successful treatment of fistula in ano with minimum chances of recurrence. In modern science cutting setons are effective in treating complex fistula in ano including those that have failed to respond other forms of surgery. It avoids preliminary internal sphincterotomy may prevent deterioration of continence. The intersphincteric ligation technique of the fistulous tract (LIFT) is done at intersphinctric groove hence it preserve both internal and external anal sphincter which avoids faecal incontinence. The VAAFT technique performed under direct vision which helps to identify any possible secondary tract or chronic abscesses. This technique is sphincter saving and surgical wounds are small. The FiLaC is safe and does not induce post-operative sepsis and have high healing rate. It is sphincter preservation minimally invasive surgery in the treatment of anal fistula. all the above modified techniques had shown sphincter saving effect and creating extremely small surgical wounds hence it avoids long duration of wound healing and recurrence of fistula in ano.

The above described techniques act at different level and produces intended effect of healing the fistulous track and reduces complications and recurrence of Fistula in ano. the new advanced techniques are effective in managing Bhagandara (fistula in ano).

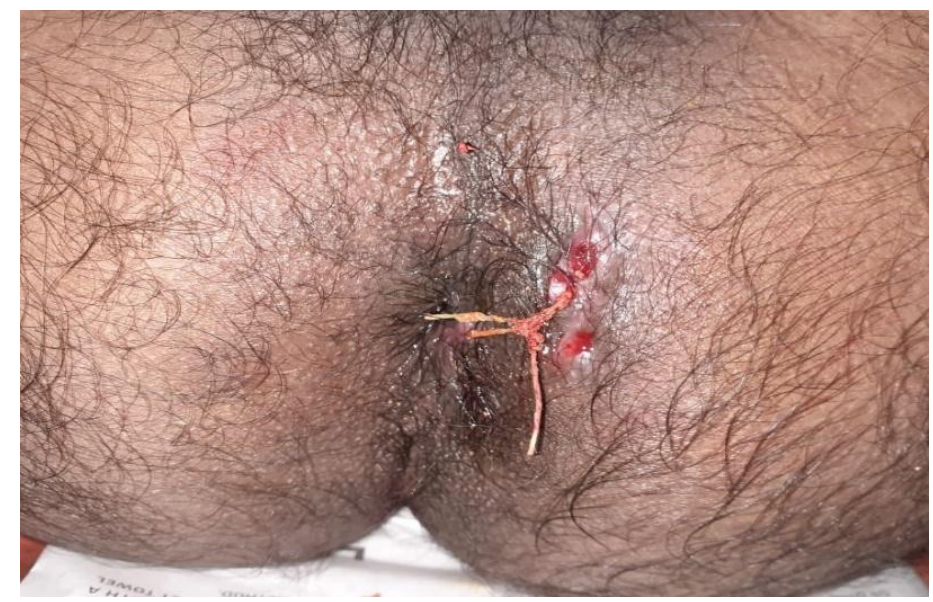

Fig. 1:- Ksharsutra Therapy 


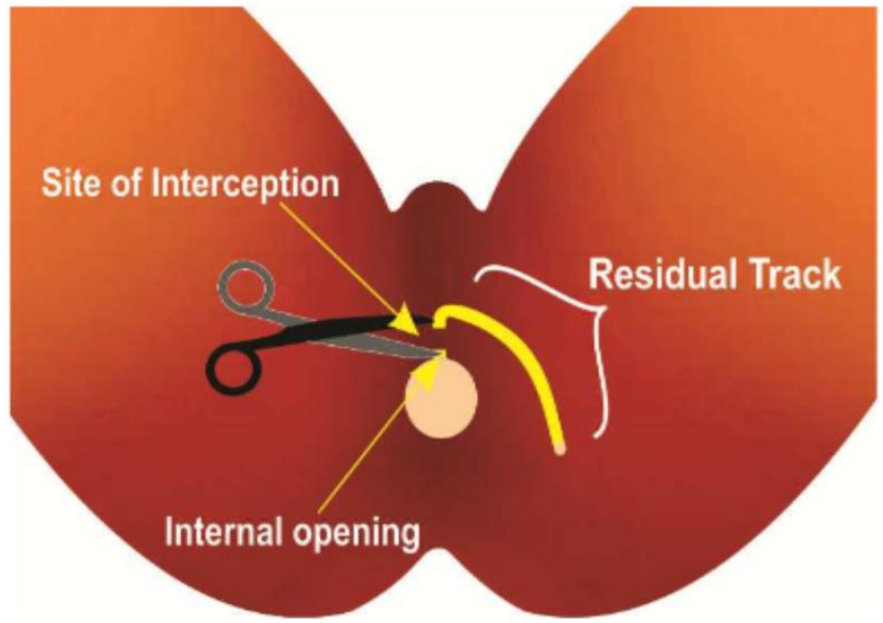

Fig. 2 IFTAK (Interception of Fistulous Track with Application of Ksharsutra)

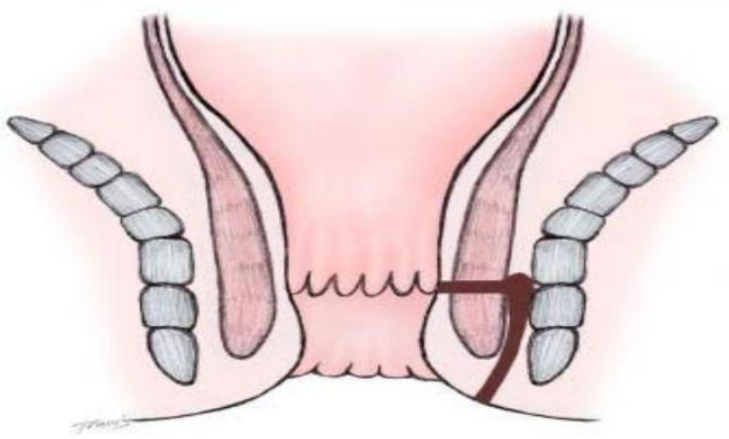

Fig. 3 Fistulotomy

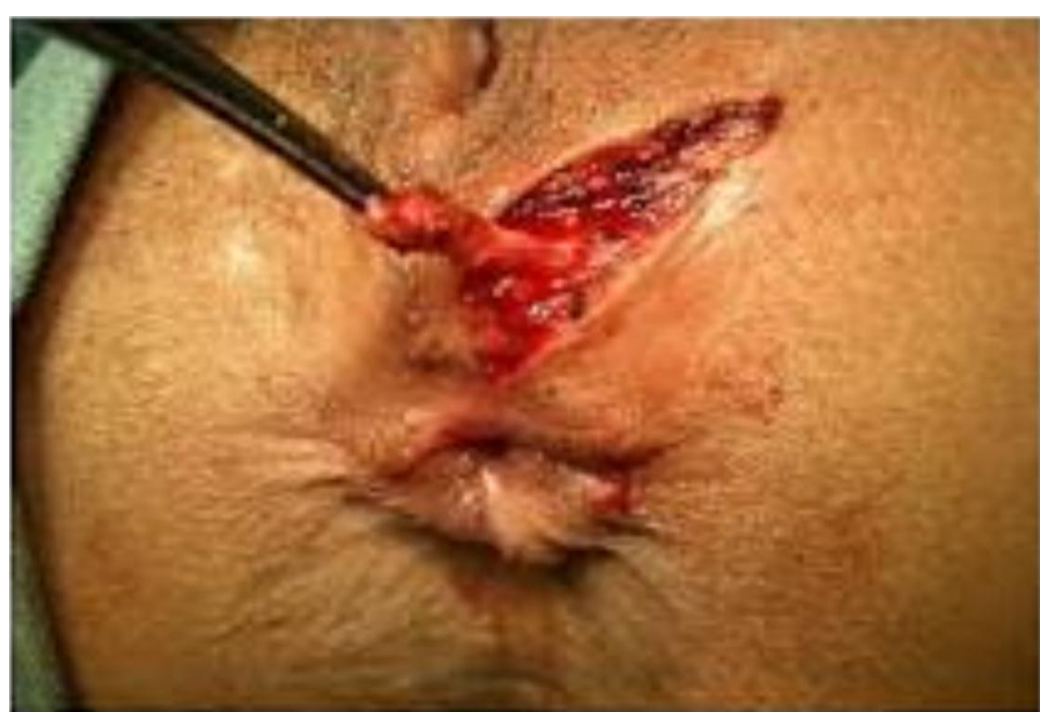

Fig. 4 Fistulectomy 


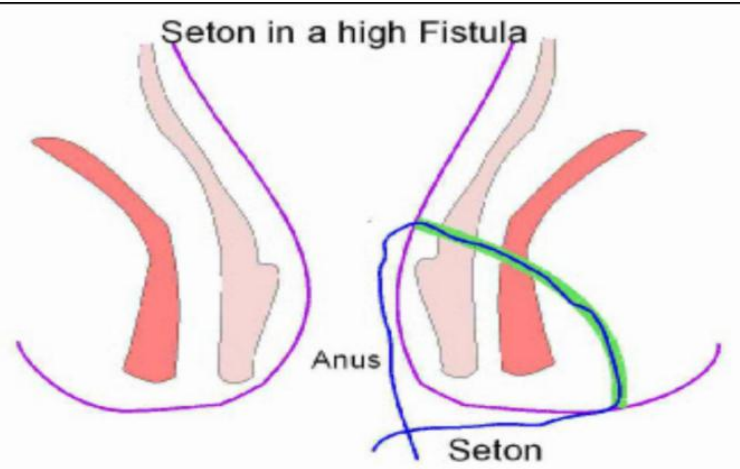

Fig. 5 Seton ligation

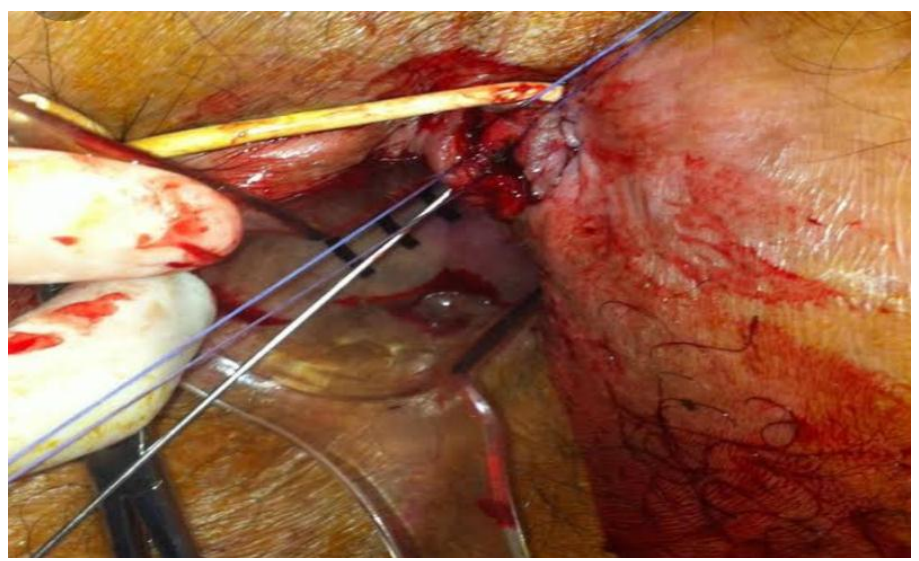

Fig. 6 LIFT (Ligation of Intersphincteric Fistula Track)

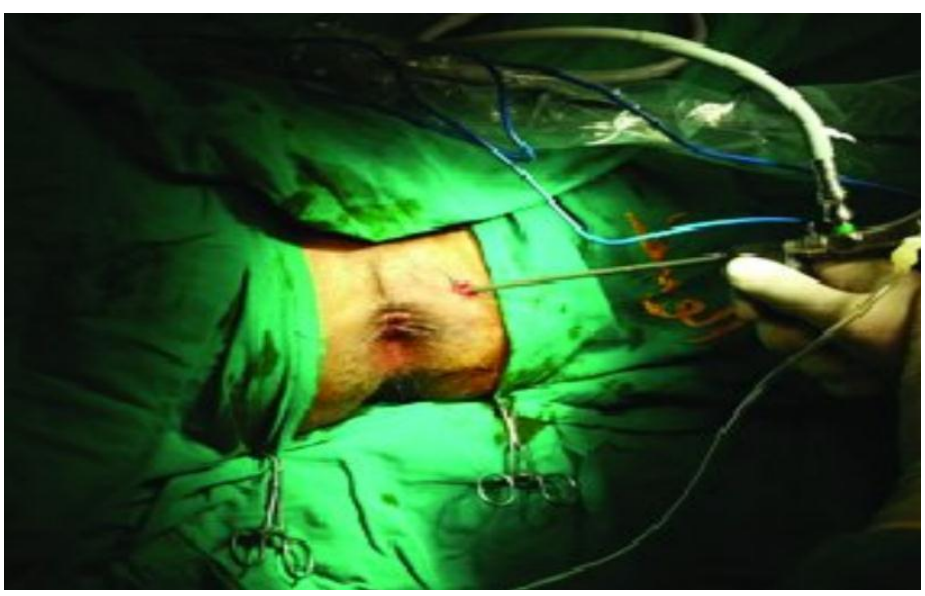

Fig. 7 VAAFT (Video-Assisted Anal Fistula Treatment) 


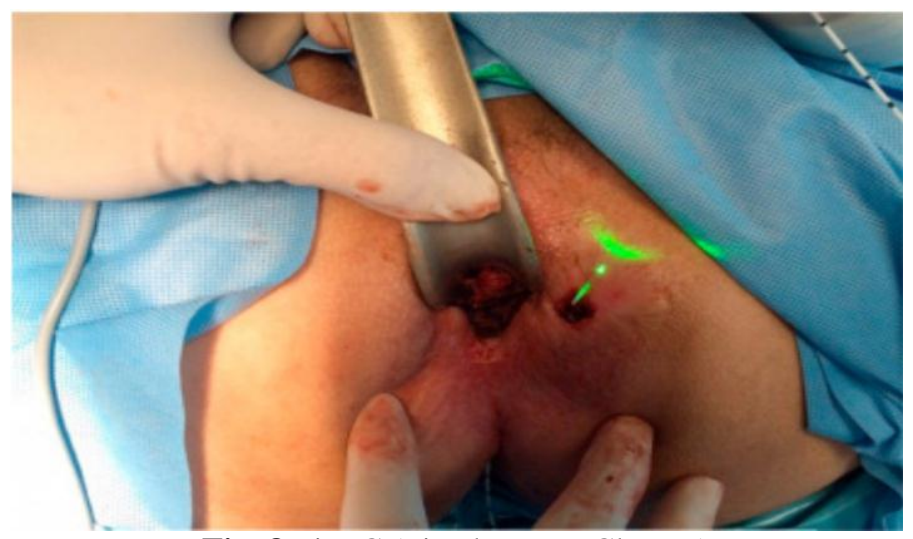

Fig. 8 FiLaC (Fistula Laser Closure)

\section{Refference:-}

1. Sharma A. Sharma P., editors. SushrutaSamhitapart-1, Sushruta vimarshini hindi vyakhya. Varanasi: Chaukhambha Surbharti Prakashan 2012 P.488.

2. Sharma A. Sharma P., editors. SushrutaSamhitapart-1, Sushruta vimarshini hindi vyakhya. Varanasi: Chaukhambha Surbharti Prakashan 2012 P.491.

3. Jadavji T. Narayan Ram.,editors. Sushruta samhita with Nibandhsangrah of Dalhanacharya. Varanasi: SurbharatiPrakashan 2018 P.438.

4. https://emedicine.medscape.com Fistula in ano updated: jun 11, 2018 [Accessed date 29/03/2019].

5. Sharma A. Sharma P., editors. SushrutaSamhitapart-1, Sushruta vimarshini hindi vyakhya. Varanasi: Chaukhambha Surbharti Prakashan 2012 P.209.

6. Kaviraj Kunjalal Bhishagratna, The Sushruta Samhita An English Translation Vol-II, Varanasi: Chowkhamba Sanskrit Series office 1991 P.339.

7. Kaviraj Kunjalal Bhishagratna, The Sushruta Samhita An English Translation Vol-II, Varanasi: Chowkhamba Sanskrit Series office 1991 P.341.

8. Deshpande P.J., Pathak S.N., Sharma B.N., Singh L.M.: Treatment of fistula in ano by Kshar Sutra. J. Res. Ind. Med., 2:131-139, 1968.

9. Sahu M, "A manual on Fistula in ano and Kshara Sutra therapy published by NRC Dept. of Shalyatantra, IMS, BHU, First edition 2015.

10. Baily and love's short practice of surgery edited by Norman S. Williams, Christopher J.K. Bulstrode, P.Ronan O'Connell, Hodder Arnold Publication $25^{\text {th }}$ Edition, Anus and Anal canal, Fistula in Ano, 1262.

11. Baily and love's short practice of surgery edited by Norman S. Williams, Christopher J.K. Bulstrode, P.Ronan O'Connell, Hodder Arnold Publication $27^{\text {th }}$ Edition, Anus and Anal canal, Fistula in Ano, 1365.

12. Baily and love's short practice of surgery edited by Norman S. Williams, Christopher J.K. Bulstrode, P.Ronan O'Connell, Hodder Arnold Publication $27^{\text {th }}$ Edition, Anus and Anal canal, Fistula in Ano, 1365.

13. Pearl RK, et al. Dis Colon Rectum. Role of the seton in the management of anorectal fistulas, 1993 jun;36(6):573-7.

14. Rojanasakul A. Tech Coloproctol. LIFT procedure: a simplified technique for Fistula in ano, sept 2009, volume 13 Issue 3, pp 237-240.

15. P. Meinero, L. Mori, Tech Coloprotocol. Video-assisted anal fistula treatment (VAAFT): a novel sphinctersaving procedure for treating complex anal fistulas, $2011 \mathrm{Dec}$; 15(4):417-422.

16. Alexandre lopes de Carvalho, Eduardo Fonseca Alves Filho, J Coloproctol. FILAC-Fistula-Tract laser closure: a sphincter-preserving procedure for the treatment of complex anal fistulas, 2017 April; 37(2): 160-162. 